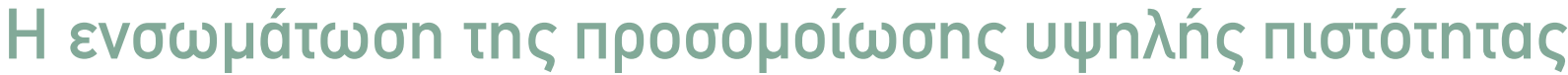

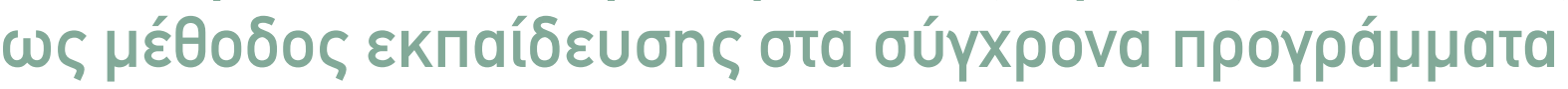

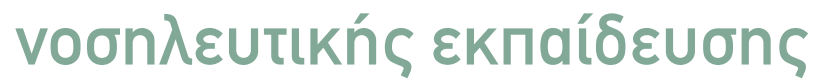

\section{The integration of high fidelity simulation as a teaching method in modern nursing}

\author{
curriculums
}

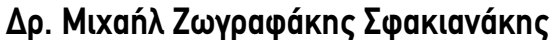

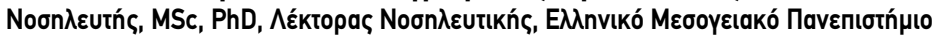

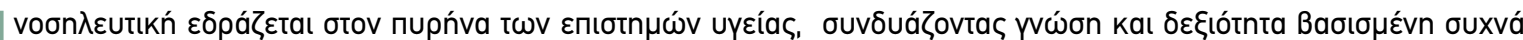

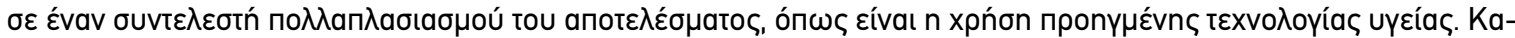

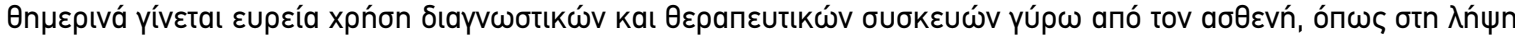

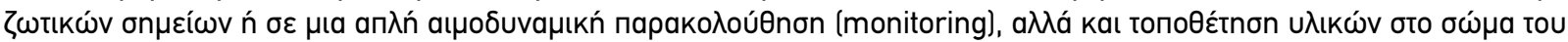

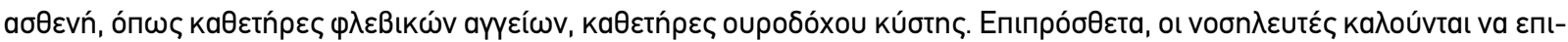

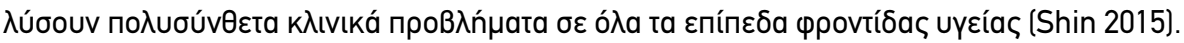

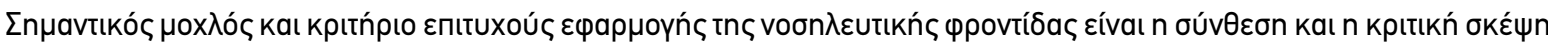

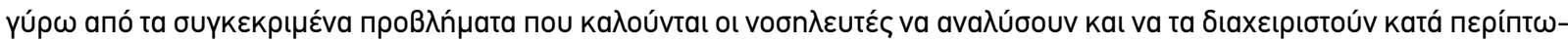
on (Papathanasiou 2014).

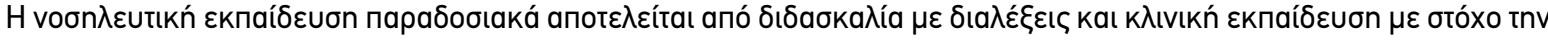

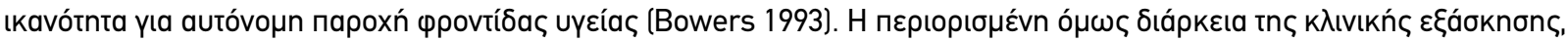

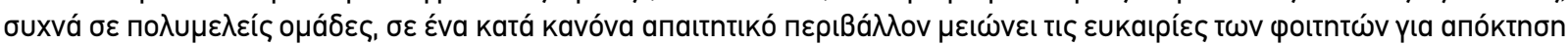

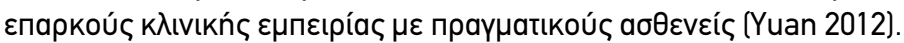

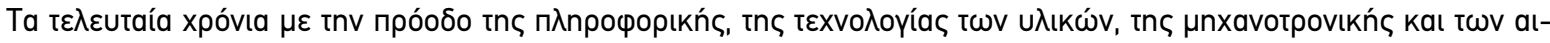

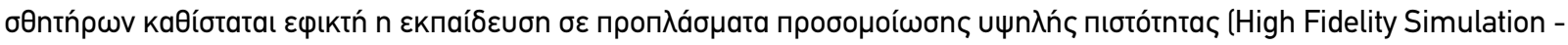

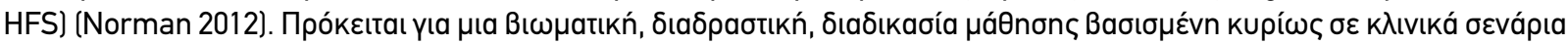

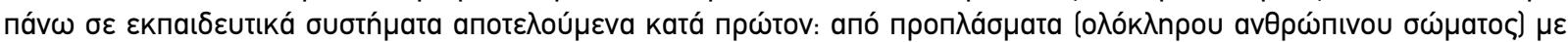

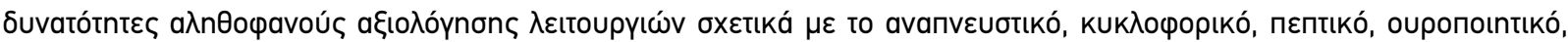

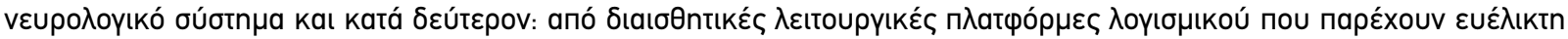

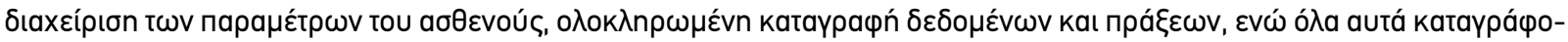

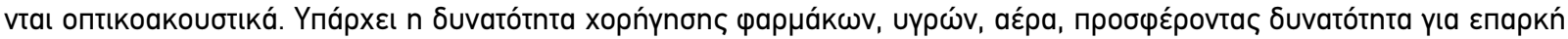

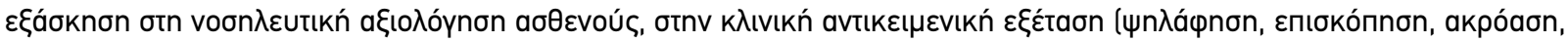

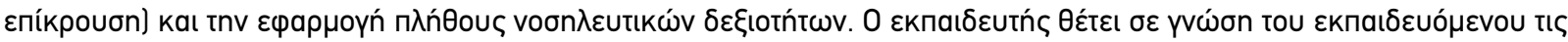

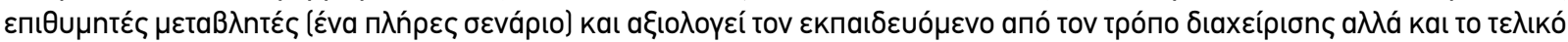

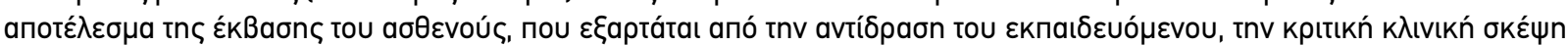

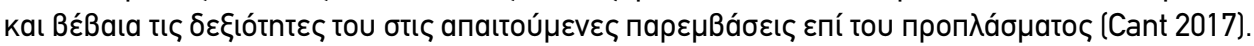

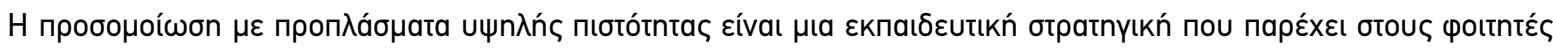

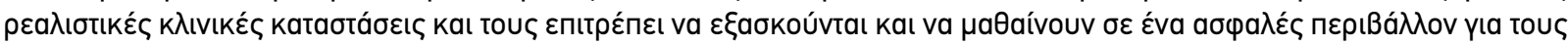
íoıous (Yuan 2012).

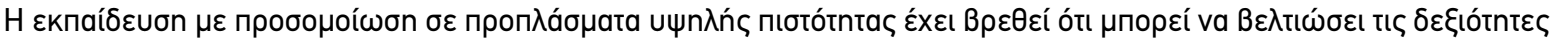

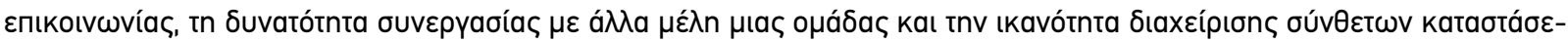

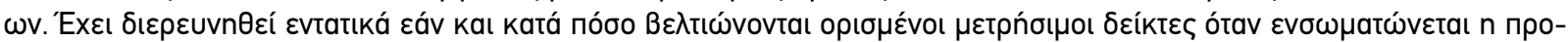

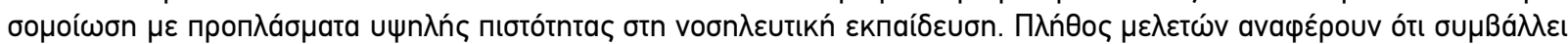

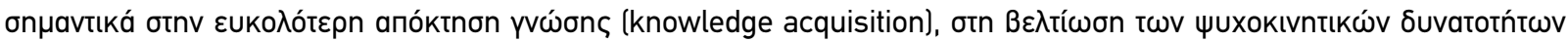

TOMOs 12 - TeYXos 2 


\section{EDITORIAL}

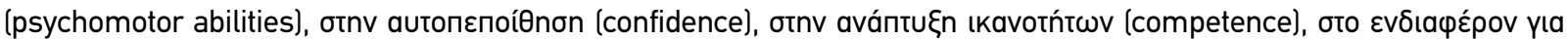

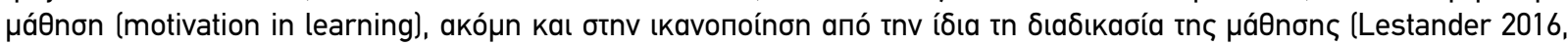
Cant 2017).

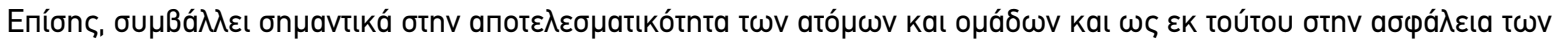

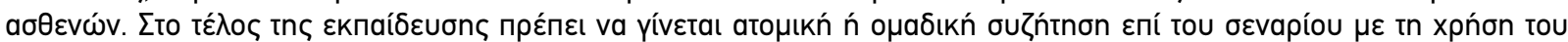

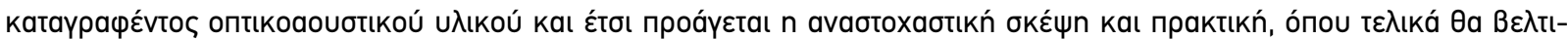

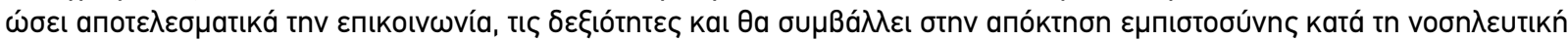

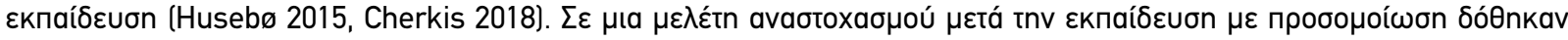

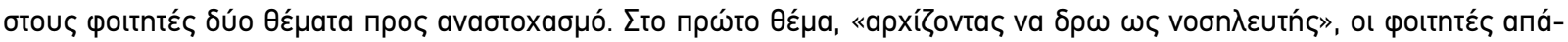

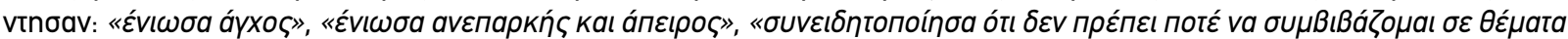

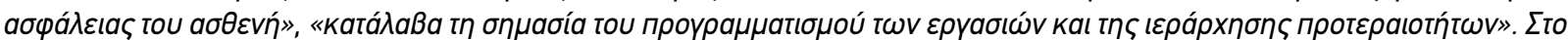

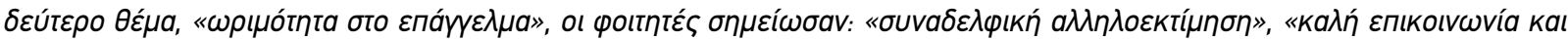

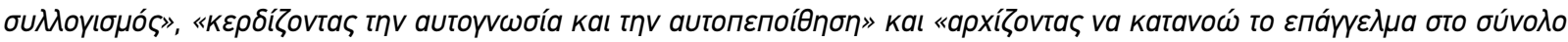
TOU» (Lestander 2016).

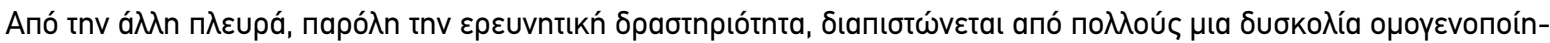

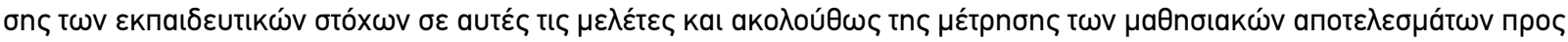

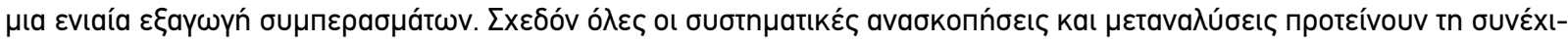

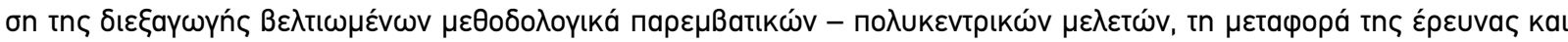

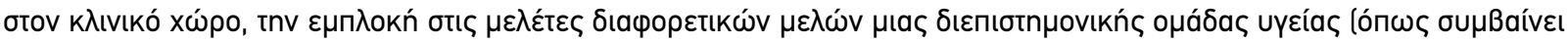

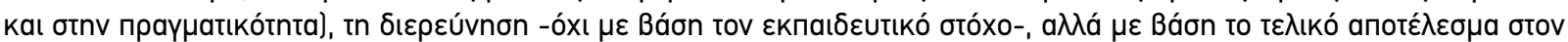

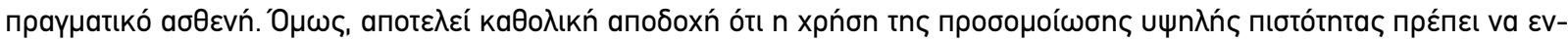

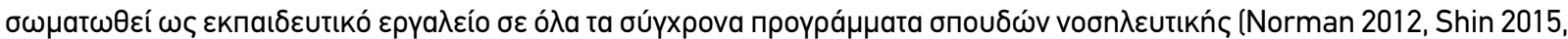
Doolen 2016, Cant 2017).

\section{BIB}

Bowers B. \& McCarthy D. (1993). Developing analytical thinking skills in early undergraduate education. The Journal of Nursing Education 32(3):107-114.

Cant R. \& Cooper S. (2017). Use of simulation-based learning in undergraduate nurse education: An umbrella systematic review. Nurse Education Today 49:63-71.

Cherkis F. \& Rosciano A. (2018). Reflective practice: Implementation across curriculums. International Journal of Nursing Research Health Care 7. doi:10.29011/ IJNHR-152.

Doolen J., Mariani B., Atz T., Horsley T., O' Rourke J., McAfee K. \& Cross C.L. (2016). High-fidelity simulation in undergraduate nursing education: A review of simulation reviews. 12:290-302.

Lestander Ö., Lehto N. \& Engström Å. (2016). Nursing students' perceptions of learning after high fidelity simulation: Effects of a three-step post-simulation reflection model. Nurse Education Today 40:219-224

Norman J. (2012). Systematic review of the literature on simulation in nursing education. The Association of Black Nursing Faculty Journal 23(2):24-28.

Papathanasiou I.V., Kleisiaris C.F., Fradelos E.C., Kakou K. \& Kourkouta L. (2014). Critical thinking: the development of an essential skill for nursing students. Acta Informatica Medica: AIM: journal of the Society for Medical Informatics of Bosnia and Herzegovina: casopis Drustva za medicinsku informatiku BiH 22(4):283-286.

Shin S., Park J.H. \& Kim J.H. (2015). Effectiveness of patient simulation in nursing education: Meta-analysis. Nurse Education Today 35:176-182.

Yuan H., Williams B. A., Fang J. \& Ye Q. (2012). A systematic review of selected evidence on improving knowledge and skills through high-fidelity simulation. Nurse Education Today 32(3):294-298.

Husebø S. \& O' Regan S. (2015). Reflective practice and its role in simulation. Clinical Simulation in Nursing 11(8):368-375.

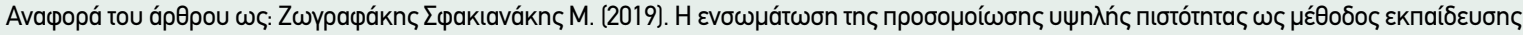

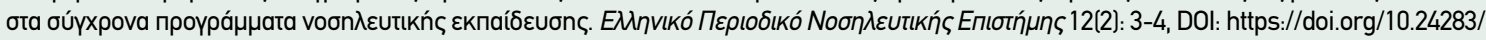
hjns.20192.3-5

Citation: Zografakis Sfakianakis M. (2019). The integration of high fidelity simulation as a teaching method in modern nursing curriculums. Hellenic Journal of Nursing Science 12(2): 3-4, DOI: https://doi.org/10.24283/hjns.20192.3-5 